Case Report

\section{First cure case of 2019 novel coronavirus in Ningxia, China}

\author{
Yifan Wang ${ }^{1}$, Pan Zhou ${ }^{2}$, Xingcang Tian ${ }^{1}$, Shuping Meng ${ }^{1}$, \\ Xiao Sun ${ }^{1}$, Ting Li ${ }^{1}$ and Li Zhu ${ }^{1 *}$
}

${ }^{1}$ Department of Radiology, General Hospital of Ningxia Medical University, China

${ }^{2}$ Department of Radiology, The Fourth People's Hospital of Ningxia, China

\section{Case presentation}

On January 19, 2020, a 28-year-old male presented to the hospital with a 2-day history of fever, occasional cough and headache. He disclosed that he worked in Wuhan [1], China (the center of novel coronavirus outbreak) and flew to Yinchuan on the day of admission.

The body temperature of the patient was elevated to $38.5^{\circ} \mathrm{C}$ $\left(101.3^{\circ} \mathrm{F}\right.$, normal range $\left.36.3-37.2^{\circ} \mathrm{C} / 97.34-98.96{ }^{\circ} \mathrm{F}\right)$. Coarse breath sounds were noted in both lungs on auscultation. Laboratory results showed white blood cell count was 4.37 $\times 10^{9} / \mathrm{L}$ (normal range, 3.5-9.5 $\times 10^{9} / \mathrm{L}$ ), neutrophils were $52.8 \%$ (normal range, $40-75 \%$ ) and lymphocytes were $35.9 \%$ (normal range, 20-50\%); C-reactive protein was $0.55 \mathrm{mg} / \mathrm{L}$ (normal range, 0-6 mg/L). Prothrombin time was $11.4 \mathrm{~s}$ (normal range, 10-14s), activated partial prothrombin time was 29.6s (normal range, 23-35s), Thrombin time was 20.3s (normal range, 13-25s) and D-dimer was $0.30 \mathrm{ug} / \mathrm{mL}$ (normal range, $0-1 \mathrm{ug} / \mathrm{mL}$ ). Unenhanced chest computed tomography (CT) showed multiple patchy ground-glass opacities and consolidation in the right middle lobe and lower lobe of both lungs (Figure $1 \mathrm{~A}-\mathrm{C}$ ). The real-time reverse transcriptase polymerase chain reaction (RT-PCR) of the patient's oropharyngeall swab specimens were positive for 2019 novel coronavirus (nCoV) nucleic acid.

Given epidemiological characteristics that the patient came from the infected area, clinical manifestations, CT findings and laboratory tests, the diagnosis of 2019-nCoV pneumonia was confirmed [2-3]. After receiving 14 days antiviral therapy with moxifloxacin $(0.4 \mathrm{~g}$ administered intravenously per day), lopinavir/ritonavir (400/100 mg administered orally every 12 hours) and interferon inhalation ( 5 million IU every 12 hours), the patient clinically improved with obviously reduced pulmonary opacities found at repeat chest CT (Figure $1 \mathrm{D}-\mathrm{F}$ ) and twice consecutive negative RTPCR. The temperature returned to $36.5^{\circ} \mathrm{C}\left(97.7^{\circ} \mathrm{F}\right)$ from January 22, and the patient discharged on February $3^{\text {rd }}$. The patient was isolated at home for 14 days after checking out of hospital to monitor temperature every day.
More Information

*Address for Correspondence: Li Zhu, PhD, Professor, Department of Radiology, General Hospital of Ningxia Medical University, China, Tel: +86- 13995172918;

Email: zhuli72@163.com

Submitted: 14 April 2020

Approved: 16 April 2020

Published: 17 April 2020

How to cite this article: Wang $Y$, Zhou P, Tian X, Meng S, Sun X, et al. First cure case of 2019 novel coronavirus in Ningxia, China. Arch Case Rep. 2020; 4: 026-027.

\section{DOI: 10.29328/journal.acr.1001035}

Copyright: $\odot 2020$ Wang Y, et al. This is an open access article distributed under the Creative Commons Attribution License, which permits unrestricted use, distribution, and reproduction in any medium, provided the original work is properly cited.

\section{D) Check for updates}

OPEN ACCESS

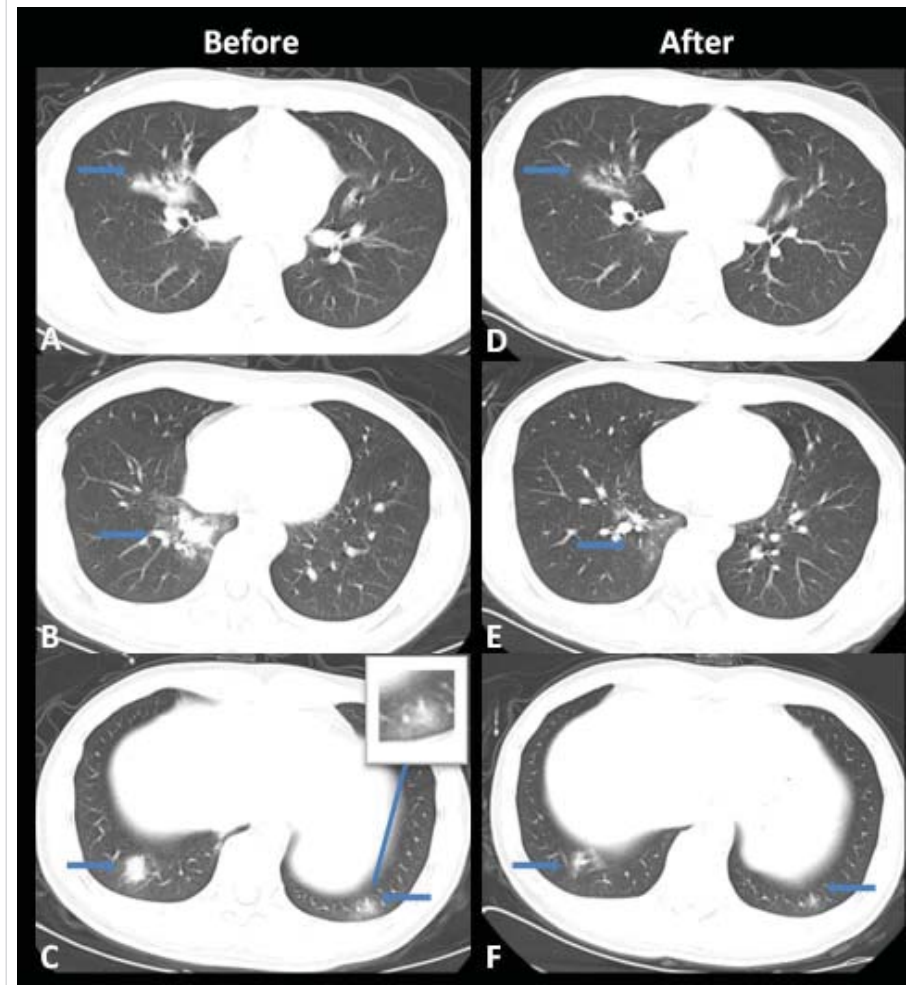

Figure 1: Thoracic non-contrast CT images in a 28-year-old male before and after treatment. (A-C), Image shows multiple patchy ground-glass opacities and consolidation in the right middle lobe and basal segments of both lower lobes. (D-F), Follow-up image on January 31 shows obviously reduced ground-glass opacities in the right middle lobe and lower lobes of both lungs. The pulmonary vascular thickening is typical CT sign of the 2019 novel coronavirus pneumonia. 


\section{Funding}

This study was supported by Ningxia key research and development plan to support the special project (2020BEG03006) and Ningxia medical university science foundation (XM2018089).

\section{Ethical approval}

Patient's data were anonymized.

\section{References}

1. Li Q, Guan X, Wu P, Wang X, Zhou L, et al. Early transmission dynamics in Wuhan, China, of Novel coronavirus-infected pneumonia. N Engl J Med. 2020; 382: 1199-1207.

PubMed: https://www.ncbi.nlm.nih.gov/pubmed/31995857

2. Chen N, Zhou M, Dong X, Qu J, Gong F, et al. Epidemiological and clinical characteristics of 99 cases of 2019 novel coronavirus pneumonia in Wuhan, China: a descriptive study. Lancet. 2020; 395: 507-513.

PubMed: https://www.ncbi.nlm.nih.gov/pubmed/32007143

3. Huang C, Wang Y, Li X, Ren L, Zhao J, et al.Clinical features of patients infected with 2019 novel Coronavirus in Wuhan, China. Lancet.395: 497-506.

PubMed: https://www.ncbi.nlm.nih.gov/pubmed/31986264 